\title{
Prospective studies urged of health risks
}

Paris. Fundamental researchers have a social responsibility to help clinicians to anticipate risks associated with the use of therapeutics of human or animal origin, according to the report of a study on such risks carried out by the French biomedical research agency INSERM.

Focusing for example on growing concern about spongiform encephalopathies which include Creutzfeld-Jacob syndrome and bovine spongiform encephalopathy (BSE) or 'mad-cow' disease - it recommends that INSERM should create a group specialising in this area because of the "uncertainties surrounding the exact nature of these agents, their genetics and epidemiology, and the absence of diagnostic tests".

The report took two years to produce, and was prepared by a task force of 68 researchers from inside and outside INSERM on the basis of a literature search that produced more than 30,000 references. Their work was complemented by discussions with a smaller number of experts in the various fields covered by the report.

The report is the first major result of a 'collective expertise' service set up last year by the research agency to "short-circuit" the traditional research timetable (see Nature $368,488 ; 1994)$. The service is intended to provide governments and companies with fast answers to contemporary questions of public health, and to analyse potential health hazards and opportunities, while simultaneously guiding INSERM's own research strategy.

The 45 chapters of the report cover topics ranging from kidney transplants to gene therapy, and blood transfusion to artificial reproduction.

Jean Rosa, the coordinator of the report and a researcher at the INSERM Laboratory of Molecular Genetics and Haematology at the Henri Mondor hospital in Paris, says that medical risks are increasingly due to the rapid progress in fundamental research. Another factor is the too-rapid application of such research because of increasing demand for new treatments.

As a result, the report concludes, fundamental research on the risks of new - and established - therapies needs to be increased. It also asserts that opportunities exist for more involvement in risk studies by fundamental researchers.

The report says researchers have a large reservoir of knowledge and skills that is not sufficiently exploited by clinicians. New treatments should be subject to prospective studies of their potential risks, it argues, asserting that promoting such work is the responsibility of researchers towards society.

Even if the so-called prion diseases are rare, says the report, they are worrying because the infectious agent has not been unequivocally identified, and is "potentially present" in foodstuffs. Such infectious and neurological complications are important, it says, because of their seriousness, their relative frequency, the attention given to them by the media, the difficulty in evaluating the risk and the threat that the medical establishment will find itself under attack.

Complaining that France generally lacks an interest in prion diseases, the report says that such research as exists lacks coordination, with little connection to related work being carried out by the agricultural research organization INRA. It proposes more epidemiological research, and research on the transmission of prions and the development of diagnostics to detect healthy carriers and diseased animals.

Declan Butler

\section{Lab rejects report that nuclear dump 'could explode'}

Washington. The Los Alamos National Laboratory in New Mexico has taken the unusual step of releasing internal peer review reports in a bid to quell public concern over suggestions by two of its scientists that a proposed underground nuclear waste repository could "go critical", triggering a chain of explosions.

The reports were extracted by Senator Bennett Johnston (Democrat, Louisiana), a supporter of the proposed repository at Yucca Mountain, Nevada, and read on the floor of the Senate in Washington last week. They say that the probability of the events predicted by the scientists, Charles Bowman and Francesco Venneri, is "essentially zero", and dismiss their work as being "of no technical merit".

In a paper prepared at Los Alamos, Bowman and Venneri had argued that plutonium and other fissile material stored in barrels underground would eventually leak, and that, mixed with rock that would act as a moderator, they could reach criticality and explode. A copy of the paper was obtained by The New York Times, which ran a frontpage story under the headline "Scientists Fear Atomic Explosion of Buried Waste" in its issue of 5 March.

Bowman, a particle physicist, is the main sponsor of a nuclear waste disposal technology called accelerator-driven transmutation technology (ADTT), which he concedes is in competition with Yucca Mountain (see
Nature 370, 404; 1994). "In the world that we live in, you look for the weakness in your competition and try to exploit it," he says, justifying the paper. Bowman's ADTT team has been pushing - without much success so far - for up to US\$500 million from the Department of Energy to build an ADTT demonstrator at Los Alamos.

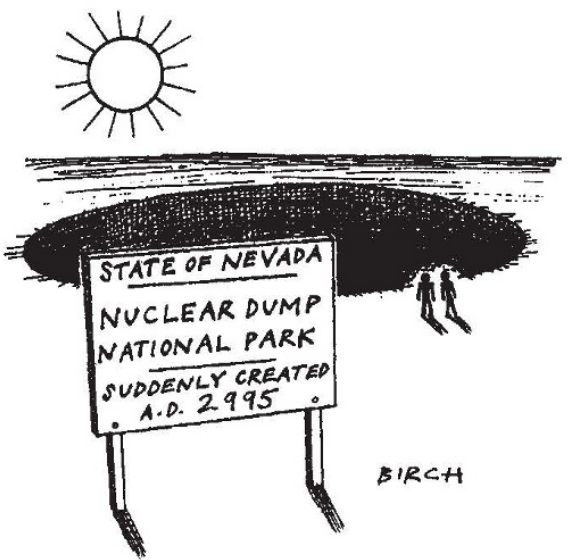

Under its internal review process, Los Alamos set up 'red', 'blue' and 'white' teams of ten scientists each to act as prosecution, defender and judge respectively in assessing Bowman and Venneri's work. The white team finished its first assessment in December, and a reassessment of a modified paper last week. It accuses the authors of "showing no grasp of elementary concepts" and making "alarmist estimates of potential effects, which have become less credible and more shrill throughout the process".

Some Senate staff members have been surprised that the Los Alamos laboratory made this damning assessment available to Johnson, but not to The New York Times when it was working on its story.

Managers at Los Alamos point out that peer review criticisms are not intended for publication, and suggest that the story got into print because Los Alamos scientists who discussed it with the newspaper "bent over backwards" to protect Bowman and Venneri. Bowman says he stands by his work that he hopes it will win support from another (unnamed) federal laboratory that is now reviewing it.

Most physicists outside Los Alamos dismiss the idea of spontaneous nuclear explosions in underground nuclear dumps for at least two reasons: that various chemical elements in rock will "poison" a chain reaction, and that, in the event of an energy release, there would be no containment mechanism to force an explosion.

But the story, which received wide television and radio coverage in the southwestern United States, is likely to linger in public perception, further undermining the energy department's already fraught efforts to store the bulk of US high-level nuclear waste at Yucca Mountain.

Colin Macilwain 